\title{
Impact of Text Discussions on the Professional Identity of Higher Education Students
}

\section{Helena Prieto Sanz}

Grup de Recerca Interdisciplinari en Educació (GRIE), Universitat d'Andorra, Andorra.

\begin{abstract}
Comprehension of academic literature is a key element in the immersion of university students in the academic subcultures of each discipline (Chanock, 2001; Estienne \& Carlino, 2004; Gottschalk \& Hjortshoj, 2004). To do so, universities opt for the implementation of text discussion such as book clubs (Hartley, 2002; Long, 2003), dialogic literary gatherings (Flecha, 2000; Mirceva \& Larena, 2010) or literary circles (Daniels, 2002; Duncan, 2012).

This case study, essentially qualitative, seeks to know the impact of text discussions on the professional identity of the students of Teacher Education and Computer Science at the University of Andorra (UdA). Results are obtained by student focus groups, the Likert test Motivational Survey on Academic Reading (Muñoz et al., 2012), teacher interviews and taking notes in situ throughout the discussions.

The main results indicate that the text discussions have a positive impact on students as (1) it increases the reflection, understanding and critique of the professional world, (2) they apply evidence-based content in professional contexts and (3) it improves the justification of informed professional decisions.
\end{abstract}

Keywords: Higher education, text discussions, professional identity. 


\section{Research goal}

The main aim of this study is to analyze the contributions of text discussions on the professional identity of UdA students.

\section{Framework}

In an increasingly dialogical society (Habermas, 2001; Beck, 1998; Flecha, et al., 2001), it is not possible to ignore the relevance of the university as an actor of the society as it becomes one of the main institutions that trains future professionals involved in the transformation of the Europe of the new century (European Commission, 2010). In the midst of this dialogicty (Bakthin, 1981), text discussions grow in university contexts: learners read a text and then meet to share interpretations and negotiate meanings. In this collective process of interthinking (Mercer \& Littleton, 2007), reading comprehension becomes a key factor in the formation of critical people with the ability to participate in the construction of a diverse and plural community (Cassany, 2006).

In this dialogical reading, students debate theoretical questions, share points of view and connect the ideas of theory with professional practice (Fernández et al., 2012). In these connections between theoretical concepts and professional actions, students critically reflect on professional practice (Freire, 1994) and, in addition, theory and practice reciprocally feed into each other (Fernández et al., 2012). Accordingly, the international scientific literature reflects the impact of text discussions on the configuration of the professional identity of the participants.

One of the contributions is the improvement of understanding of the professional world (Macoun \& Miller, 2014) as students reflect and take a critical position towards professional real context (Aguilar, 2017). In this sense, several studies whose participants are Teacher Education students collect results on how they reflect on the teaching practice and the role of the educator in classrooms (Flood et al., 1994; Finke \& Edwards, 1997; Aguilar, 2017). For example, they reflect and dialogue about the impact the educator has on student participation in the classroom (Chocarro de Luis, 2013).

On the other hand, readers are also questioning values and principles that will guide their actions in the professional context. As an example, Bixler and colleagues (2013) collect how students become aware of the need to be readers in order to teach reading. In this reflective process, the awareness of the need for informed and justified professional decision-making based on scientific evidence raises (Aguilar, 2017) and the ability to argue upon scientific bases also improves (Bixler et al., 2013).

Moving from reflection to practice, HE students also apply the contents learned in classsroom. In this line, different studies developed in Teacher Education show how students 
have transferred or intend to implement the reading groups as a teaching strategy in schools (Finke \& Edwards, 1997; Bixler et al., 2013; Chocarro de Luis, 2013). Some arguments that motivate the transfer of this teaching strategy are that it is conceived as a way to expand ideas towards the same content through peer interactions or as a way to give learning opportunities to all students, including those who are shyer and less participatory (Flood et al., 1994).

\section{Methodology}

This research is an essentially qualitative case study (Yin, 2009). Quantitative data are also obtained in order to expand and delve into specific aspects (Hesse-Biber, 2010). This triangulation adds greater breadth, richness, and depth to the study (Flick, 2007, cited by Denzin, 2012).

On the one hand, qualitative data are obtained through the application of interviews and discussion groups with faculty and university students. On the other hand, we obtain quantitative data through the tool Motivational Survey towards Academic Reading (Muñoz et al., 2012) applied to the students. At the same time, we make observations of the text discussion sessions and on-site notes are collected.

\section{Results}

First, we note an improvement in the reflection, understanding and critique of the professional world. Students express how focus groups allow them to better understand their future profession. For example, a student expresses how the relationships between the content and other topics such as personal experiences or contextualized real cases favor a deeper understanding of the professional world in which they will enter once they have completed their training:

I understand more context for global world. This contextualization [in group discussions] helps me to understand better my task in the professional world. (BAE1819_A4)

At the same time, participants reflect on the professional figure in their daily work. We observe it on the words of Teacher Education students when they reflect on the role of the teacher. These reflections are possible thanks to the internships that students do in schools:

BCE1819_P: The language is also important.

BCE1819_A9: Is that what the author was saying, that talking about architecture with an architecture student is not the same as talking about a K12 child, adapted!

BCE1819_A8: adapted because there are parents who talk to their children as if they were a baby and it's not good either because the children talk fatally! 
And the teachers always try to say the sentences well and not say "woof, woof" and things like that.

In this dialogic learning environment, students become involved in the process, work on the content in depth and try to understand it from multiple perspectives and, finally, implement somehow the contents learned in class. As we have seen, participants are able to more easily establish connections between theory and practice and, consequently, they transfer the content worked on together to a real professional context in an easier way. The following excerpt recounts the widespread perception among Teacher Education students:

Yes, I think so [that the reading groups have helped us in our professional action]. I think it helps you because you remember it, it's something you've worked on, that you've understood and at the moment you say "okay, I'm watching it and I know how to apply it, I know what to do". (BCE1819_A6)

This links between theory and practice are also recorded in the field notes. For example, we notice how some students make direct references to the assessment challenges they have to undertake and the theory that they have adressed in class:

I liked the text, I find it very interesting. Overall, the reading is great, especially the part of our challenge that says the teacher needs to stimulate dialogue which is very important for children's cognitive and moral development. (BCE1920_A6)

In addition, we observe how students discuss and help each other by expressing ideas, modifications and innovations that they would make in the written work of their classmates:

BCE1920_A6: My activity is about I cooking, right? They make the recipe, when they have the recipe they give it to the teacher and the teacher cheats them, that is, the teacher puts them in liters and they have to convert [to another unit].

BCE1920_A5: if it is for the measures, with conversion of units. For example, to put a problem could be "we have this meter in $\mathrm{ml}$ and I have the recipe with $l^{\prime \prime}$.

BCE1920_A3: or do what he [partner] just told you, for example "this is for seven children, how much would it be if it were for more?

On the other hand, some participants confirm that they have directly applied certain strategies worked on in the classroom based on reading and group discussion. We see some cases related to mathematical or teamwork strategies:

Yes. For example, teamwork, group strategies, yes I did it in the first cycle, they do a lot of group strategies! (BCE1920_A3) 
The other day [at school] we had a literary gathering and... about maths, they did fruit series. Then, the students ended up eating fruit skewers while doing the literary gathering. (BCE1819_A3)

These student accounts are in line with the ratings scored in the survey. When students are asked about whether reading academic literature will help them become a good professional, we see an increase in students' perception of the usefulness of academic texts in their development as a professional (Table 1).

Table 1. Criteria of Motivational Survey on Academic Reading related to the usefulness of academic reading.

\begin{tabular}{|c|c|c|c|}
\hline & \multicolumn{2}{|c|}{ Average } & Var. \\
\hline Reading academic literature will help me to be a good professional & 3,654 & 3,99 & $+9.2 \%$ \\
\hline
\end{tabular}

At the same time, an improvement in the justification of informed professional decisions is identified. The use of scientific evidence in informed professional decisions becomes a key factor in achieving excellence in professional contexts. In this sense, we identify several experiences of both Computer Science and Teacher Education students who use or in the future will use a scientific basis for the development of their professional tasks:

BCE1819_A5: about separating groups, it is true that we have seen that it much better to separate them with some criteria, these criteria we have seen in scientific sources.

BCE1819_A6: Yes, they are things we have already seen and we could work with what we know.

We note several samples of how students include scientific evidence in the design and planning of activities which are going to be implemented in the school as well as in their future professional work. In the following example, the student uses theories from classical authors such as Piaget and Vygotsky in order to justify his decisions. As he says, the knowledge built in the group discussions "helps you to develop your daily work":

What I have seen is that perhaps, with Vygotsky's ZPD, we should always take into account elements that are close to children or that are not something completely decontextualized from their environment, but something that is from their daily lives. And I do try to apply that, for example, if I have to bring them a material of whatever, then I try to bring materials that they can find at home or with examples that are in their everyday or things like that. I always try to apply that. (BCE1819_A5)

At the same time, students exemplify the usefulness of using scientific evidence for the development of professional work. The following excerpt summarizes how Computer 
Science students attach importance to research as it provides reliable knowledge regarding the comparison of new systems and technologies, useful information for scientifically supported job performance:

The third reading we saw one method against the other, it was clearly more powerful. Based on that article you discover that and, perhaps, you can find an article where you compare two technologies that you are interested in implementing in your company or whatever and you see that one is better than the other, more like a benchmark, a comparison between two or more. (BI1819_A2)

Finally, students also consider the use of primary sources important because it brings them closer to real professional contexts: they know what difficulties researchers have faced and allow them to learn the theory applied to real professional situations, with its limitations and difficulties. We retrieve the following fragment as an example:

BI1819_A4: yes [the seminars have helped us to better contextualize the theory in the real world], because we see a real case of someone who has applied... it is not just to say: "look, this protocol works like this", but you can say "look at the protocol, it is implemented with this technology, these servers have been needed."

BI1819_A3: When you learn is when you are working and you find yourself in trouble and the university does not give you that... you learn it by working! And here, in the readings, we have seen difficulties that have come out that have helped us to analyze things, which is obviously much more extensive and infinite, but look, you already have things in mind that you don't have to do.

\section{Discussion of research outcomes}

As we have seen, text discussions directly affects the configuration of the professional identity of the HE students. First, there is a greater reflection, understanding and critique of the professional world. On the one hand, the relationships between the content and other topics such as personal experiences or contextualized real cases favor a deeper understanding of the professional world, in line with previous studies (Flood et al., 1994; Finke \& Edwards, 1997; Bixler et al., 2013; Chocarro de Luis, 2013; Macoun \& Miller, 2014; Aguilar, 2017).

On the other hand, the dialogic scenario of the discussion groups contribute very favorably to the motivation of the students to consider and finally incorporate the new contents and the new teaching strategies learned in the framework of the reading activity. Similarly, other researchers have identified how students have transferred group text discussion as a teaching strategy during internship programs (Flood et al., 1994; Finke \& Edwards, 1997; Bixler et al., 2013; Chocarro de Luis, 2013). 
In addition, students show an increase in awareness of informed and justified decisionmaking based on scientific evidence (Aguilar, 2017) when, for example, they discuss what the teacher's daily work at school would be according to the theory. But beyond this increased awareness, participants show a clear interest in using primary academic literature and including this scientific basis in their early professional actions. As part of this study, students are already considering scientific evidence in the design and planning of activities to be implemented in the school.

\section{References}

Aguilar, C. (2017). La tertulia pedagógica dialógica en el practicum de la formación inicial de maestras y maestros. Revista Iberoamericana de Educación, 73(2), 9-22. https://doi.org/10.35362/rie732198

Bakhtin, M. (1981). The dialogic imagination: Four essays. University of Texas Press.

Beck, U. (1998). La sociedad del riesgo: hacia una nueva modernidad. Paidós.

Bixler, J., Smith, S. \& Henderson, S. (2013). Inviting Teacher Candidates into Book Talks: Supporting a Culture of Lifelong Reading. Reading Horizons, 52(3), 233-254.

Cassany, D. (2006). Tras las líneas. Sobre la lectura contemporánea. Anagrama.

Chanock, K. (2001). "From mystery to mastery". Actas de la Conferencia Australiana sobre Lenguaje y Habilidades Académicas. Changing Identities. Universitat de Wollongong.

Chocarro de Luis, E. (2013). Las tertúlias dialógicas, un recurso didáctico en la formación de docentes. Historia y Comunicación Social, 13 (November), 219-229.

Comissió Europea. (2010). Comunicación de la Comisión Europa 2020. Una estrategia europea para un crecimiento inteligente, sostenible e integrador. (Bruselas, 3.3.2010 $\operatorname{COM(2010)} 2020$ final). Comisión Europea. https://bit.ly/3uhKdiD

Daniels, H. (2002). Literature circles: Voice and choice in book clubs and reading groups. Stenhouse Publishers.

Denzin, N. K. (2012). Triangulation 2.0. Journal of mixed methods research, 6(2), 80-88.

Duncan, S. (2012). Reading circles, novels and adult reading development. Bloomsbury Publishing.

Estienne, V. \& Carlino, P. (2004). Leer en la universidad: enseñar y aprender una cultura nueva. Uni-Pluri/Versidad, 4(3), 9-17.

Fernández, S., Garvín, R., \& González, V. (2012). Tertulias pedagógicas dialógicas: Con el libro en la mano. Revista electrónica interuniversitaria de formación del profesorado, 15(4), 113-118. https://revistas.um.es/reifop/article/view/174861

Finke, J., \& Edwards, B. (1997). Teacher Education Students' Insights From Intergenerational Literature Circles. Journal of Teacher Education, 48(5), 367-378.

Flecha, R. (2000). Sharing Words: theory and practice of dialogic learning. Rowman \& Littlefield.

Flecha, R., Gómez, J. \& Puigvert, L. (2001). Teoría Sociológica Contemporánea. Paidós. 
Flood, J., Lapp, D., Alvarez, D., Romero, A., Ranch-Buhr, W., Moore, J., Jones, M.A., Kabildis, K., \& Lungren, L. (1994). Teacher book clubs: a study of teachers' and student teachers' participation in contemporary multicultural fiction literature discussion groups. Reading Research Report No. 22, (National Reading Reserach Center (NRRC)), 1-32.

Freire, P. (1994). Cartas a quien pretende enseñar. Siglo XXI.

Gottschalk, K. \& Hjortshoj, K. (2004). The elements of teaching writing. Bedford/St. Martin's.

Habermas, J. (2001). Teoría de la Acción Comunicativa. Taurus.

Hartley, J. (2002). The Readings Groups Book. Oxford University Press

Hesse-Biber, S. (2010). Qualitative approaches to mixed methods practice. Qualitative inquiry, 16(6), 455-468.

Littleton, K., \& Mercer, N. (2013). Interthinking: Putting talk to work. Routledge.

Long, E. (2003). Book Clubs:Women and the Uses of Reading in Everyday Life. University of Chicago Press.

Macoun, A., \& Miller, D. (2014). Surviving (thriving) in academia: feminist support networks and women ECRs. Journal of Gender Studies, 23(3), 287-301.

Mirceva, J., \& Larena, R. (2010). Dialogic imagination in literacy development. Revista de Psicodidáctica, 15(2), 191- 205.

Muñoz Valenzuela, C., Ferreira Torres, S., Sánchez Quintul, P., Santander Pérez, S., Pérez Rodríguez, M., \& Valenzuela Carreño, J. (2012). Características psicométricas de una escala para caracterizar la motivación por la lectura académica. Revista electrónica de investigación educativa, 14(2), 118-132. https://bit.ly/3hd9K9c

Yin, K.R. (2009). Case Study Research. Design and Methods. Fourth Edition. Applied Social Research Methods Series. Volume 5. London: SAGE. 